\title{
Belgeo
}

Revue belge de géographie

2-3 | 2017

Une géographie sociale de l'enseignement/A social geography of education

\section{School segregation in four Italian metropolitan areas}

Rescaling, governance and fragmentation of immigration policy

La ségrégation scolaire dans quatre régions métropolitaines italiennes. Échelle territoriale, gouvernance et fragmentation de la politique d'immigration

\section{Eduardo Barberis and Alberto Violante}

\section{(2) OpenEdition}

1 Journals

Electronic version

URL: http://journals.openedition.org/belgeo/19018

DOI: $10.4000 /$ belgeo.19018

ISSN: 2294-9135

Publisher:

National Committee of Geography of Belgium, Société Royale Belge de Géographie

\section{Electronic reference}

Eduardo Barberis and Alberto Violante, "School segregation in four Italian metropolitan areas », Belgeo [Online], 2-3 | 2017, Online since 31 December 2016, connection on 03 May 2019. URL : http:// journals.openedition.org/belgeo/19018; DOI : 10.4000/belgeo.19018

This text was automatically generated on 3 May 2019.

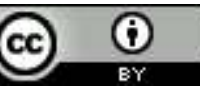

Belgeo est mis à disposition selon les termes de la licence Creative Commons Attribution 4.0 International. 


\title{
School segregation in four Italian metropolitan areas
}

\author{
Rescaling, governance and fragmentation of immigration policy \\ La ségrégation scolaire dans quatre régions métropolitaines italiennes. Échelle \\ territoriale, gouvernance et fragmentation de la politique d'immigration
}

Eduardo Barberis and Alberto Violante

\section{Introduction}

1 The criticism towards methodological nationalisms is more and more shared in social sciences, and has boosted the attention on territorialized institutional processes. In this respect, the approach to the rescaling of statehood (Brenner, 2004) is focal to analyse territorial changes and related institutional adaptations.

2 Immigration policy has been more and more studied in its territorial dimension, too: localized processes and actors are related to complex scalar relations, with place-specific configurations producing distinct models of integration. Local policies affect migration and integration processes in relation to scalar factors such as the positioning of different locales in urban and regional hierarchies and the transformations of local economy (Glick Schiller, Caglar, 2010). The localized regulation of policies (including education and immigration) may reinforce selective, exclusionary and othering practices detrimental to vulnerable groups, such as international migrants.

3 Starting from this perspective, this article analyses school segregation of Pupils from Immigrant Backgrounds (from here on, PIBs) ${ }^{1}$ and policies targeting them in Italian schools. This policy area is a privileged observation deck of the territorial dimension of migration policy, where settlement patterns and institutional coping meet. Analysing school segregation means focussing on the relationship between minorities and an important State agency of socialization - with the local dimension playing a focal role due to the devolution of educational organizations and the effects educational agencies have on restructuring local communities (as welfare institutions coping with social needs, and 
as producers of inputs for local labour markets, see Lipman, 2010). The scalar configuration will be disentangled by analysing the relationship between local economies and settlement patterns, that intermingle with national and regional regulation patterns in defining risks of school segregation.

The focus will be on four metropolitan areas, chosen according to their size, relevance as migration hubs (Pugliese, 2008), diversity of local welfare and position in national and international urban hierarchies - framing factors in the constraints and opportunities of managing migration. We analysed the two largest Italian metropolitan areas, Milan and Rome, plus a well-off Northern Italian city with a comparatively generous and structured municipal welfare, and a Mediterranean city that is the largest migration hub in Southern Italy and has a residual local welfare (Kazepov, Barberis, 2012).

As for their economic position, Bologna and Milan are regional manufacturing centres, even though Milan itself and Rome are also national and international service hubs. Finally, Naples is a smaller labour market with a strong tertiary vocation, but also a non negligible secondary sector.

6 Metropolitan size and labour markets influence migration settlement and PIBs' characteristics: service economies in Milan and Rome attract a number of immigrants in the core city, though in affordable peripheral areas; the mix of service and industrial sprawl in Bologna and Naples favours a dispersal in the larger metropolitan area. Immigrant families with children follow similar paths, with quite a concentration of PIBs in (often disadvantaged) suburban areas.

7 This article is based on research activities that took place within the framework of two projects: (a) a project of national interest (PRIN 2006) on the local dimension of social policy; (b) a FP7-funded project on the Governance of Educational Trajectories in Europe ( GOETE). Within the first one, a research campaign on local immigrant policies has been conducted (years 2007-2010), with a collection of local policy documents (retrieved from welfare plans produced by the Regions); interviews with local policy makers ( $n=20,5$ per city); interviews based on the vignette technique, i.e. a simulation of case histories to be discussed with street-level bureaucrats (mostly social workers, $n=40$ - between 8 and 12 per Region); the construction of a dataset on schools and students that based the analysis of segregation. Within the second one (years 2010-2012), a document analysis (this time at national level) and interviews to national and local policy makers and educational professionals ( $\mathrm{n}=15-6$ at national level, 2 in Milan, 5 in Bologna, 2 in Rome) were conducted.

8 The argument will be deployed by contextualizing first the main features of the Italian education system and the role of PIBs in it. As a second step, we will explore regional policies targeting migrant youth, and lastly, the main features of school segregation will be analysed. Conclusions will wrap up different parts of the argument.

\section{Setting the stage: the Italian education system, its governance and the position of PIBs}

\section{Main features}

Italy has a comprehensive (i.e. formally not selecting intakes according to skills or social conditions) education system since 1962. The Ministry of Education governed this system 
in a bureaucratic-hierarchical way, despite a well-known and long-lasting territorial cleavage (Grimaldi, Serpieri, 2012). Centralism has been eroded by waves of decentralization, in the 1970s (regionalization of vocational training; definition of representative bodies in schools), and during the 1990s-2000s (increased school autonomy: managerial role of the principal; definition of curricula, extra-school services and organization of teaching activities). Decentralization climaxed with the constitutional reform in 2001, which expanded the financial and legislative role of Regions, also in the field of education and training. Regions and local authorities are also responsible for the establishment and location of schools in their territory, and for public transport of pupils, thus defining some policy conditions for segregation. ${ }^{2}$

Compulsory education is organized in two cycles: the first one includes two tiers providing general education - primary (ISCED 1, pupils aged 6-11) and lower secondary schools (ISCED 2, pupils aged 11-14); the second one includes institutions with different specializations and durations - upper secondary schools (with vocational, technical and general tracks) and regional vocational training (ISCED 3, pupils aged 14 to 17/19).

11 These schools are mostly in a public State system: private schools account for $12.9 \%$ of Italian pupils and $9.8 \%$ of foreign ones - mostly in pre-primary education.

12 Formally, the choice of schools at every level is free: school zoning exists, but mainly for organizational reasons (public transport, coordination among schools...) with no binding enrolment scheme; all different specializations in upper secondary schools can be accessed, whatever the entry level.

\section{Emerging criticalities}

13 In the intersection of traditional (e.g. class and territorial divides), new problems and institutional responses, it is possible to stress some governance weaknesses in the Italian education system, to which we will return:

- an inconsistent governance structure (mainly hierarchical and bureaucratic), that results in blurred school autonomy and in promoting just formally decentralization;

- a decentralization that set up an unclear division of tasks and responsibilities between levels, further institutionalizing a traditionally strong territorial divide;

- an unreformed lower secondary tier, a weak point in the educational path;

- a challenge to the traditional integrative and comprehensive school model raised by the new profiles of pupils and families.

14 "Universal" in its welfare aims, the Italian education system proved to be selective in practice, with tracking effects and problems in granting equality and social mobility in a "blocked society" where social and regional backgrounds are strong determinants of intergenerational inequalities (Ballarino, Checchi, 2006; Ballarino et al., 2009; Schizzerotto et al., 2011).

\section{PIBs in the educational system}

A growing number of PIBs is one of the challenges the Italian education system faced in the last two decades. The number of non-Italian citizens in Italian schools grew from less than 200,000 in 2001 to some 815,000 in 2014 (9.2\% of all pupils), with a growing share of those born in Italy (now more than 55\%, see Santagati, Ongini, 2016). The largest groups 
(accounting for more than 50\% of the total) have Romanian, Albanian, Moroccan and PRC citizenship. This trend paralleled the increased of the immigrant population as a whole, since in the same years foreign residents grew from 1,3 to 5 million.

School tracking is particularly relevant for PIBs: vocational education is attended by $19 \%$ of Italian pupils and 37\% of PIBs (ibid.). Tracking is matched with delayed school careers: almost two thirds of PIBs experience delays in their regular attendance at the age of 15 , with an impressive gap in the hold back rate. National and international students' assessment show also a gap in competences, matched with a high regional variation.

Notwithstanding a good production of national documents on intercultural education, the policy on paper hardly find a way in the actual practice: localized differences are not compensated, and school integration is basically related to regional, local if not schoollevel priorities and investments.

A good example comes from a supposedly "anti-segregation" national rule issued in 2010, defining a threshold of $30 \%$ PIBs per class. Poor grasp on local characteristics of migration (differences among the PIBs, numbers already higher than the thresholds in many locales, with no way to cut the share) and the implementation autonomy left at the local level made the measure merely symbolic and inadequate to cope with emerging concentration factors.

\section{Subnational policies. The regional and municipal level}

19 The territorial levels of government play a relevant role. We provide here a short account of regional and local measures (in Lombardy/Milan; Emilia-Romagna/Bologna; Latium/ Rome; Campania/Naples), to disentangle the relationship between scales and practices in affecting settlement and segregation patterns.

\section{The regional level}

\section{The resources}

It is not easy to assess social expenditure targeting minors from an immigrant background: they access both dedicated (e.g. mediation) and mainstream measures (e.g. free textbooks, scholarships, juvenile social service...), but there are rarely data on users.

The ISTAT survey on municipal social services includes the area "immigration and Roma people", that makes up a limited share of local social expenditure: in 2012, it ranged from $1.6 \%$ in Campania to $4.7 \%$ in Latium (where anyway it is largely used for the Roma people target), passing for $2.1 \%$ in Lombardy and 3.4\% in Emilia-Romagna. It means a per-capita yearly expenditure of $€ 26$ in Campania and Lombardy, $€ 52$ in Emilia-Romagna and $€ 98$ in Latium.

Expenditure has been decreasing in the years due to the negative effect of political debate on the issue and the end of national earmarked transfers after the implementation of the 2001 Constitutional Reform (Napolitano, 2012).

23 Further information can be found in regional deliberations on budget, to understand how much Regions steer their municipalities. Direct regional resources during the 2000s have been quite limited, accounting for some $20-25 \%$ of total local expenditure (Kazepov, Barberis, 2012). 


\section{Policy priorities and institutionalization of measures} according to place-specific characteristics. Problems are less tough in areas where immigration is less an issue in the policy debate; where politics support pro-immigrant policies; where there are specific skills in the policy network of public and private actors. 
As an example of a national system that "passes the buck" of integration problems to the micro-local level, in this section we analyse school segregation processes at local level. We maintain, as suggested above, that school segregation is shaped according to patterns typical of systems with low institutional regulation. Data about pupil's enrolment by nationality (Italian / foreign) in any single school came from the Minister of Education. To measure segregation, we used Theil's h-index, taken as a proxy of uneven distribution, which ranges from 0 (no segregation) to 1 (complete segregation). The index, originally presented by Theil (1972), is also known as the multigroup information index and must be interpreted as the weighted average of the difference between the whole diversity and the specific diversity of a single area. It is well-known in literature that there is large correlation between H index and the classic Dissimilarity index based on the Lorenz curve (Duncan and Duncan, 1995), which rather measures evenness through another of its dimension: concentration. We choose $\mathrm{H}$ index because it is less sensitive to the measurement of small groups ${ }^{3}$ and allows to decompose segregation at different 
territorial levels (see Figure 1), consistently with our interest for scales. We analysed components according to the example by Reardon et al. (2000).

The $\mathrm{H}$ index has been divided into 4 components (see Figure 1), measuring segregation:

- between schools in the metropolitan area and in the core municipality $(\mathrm{Hcm})$, whose boundaries have been marked with a thick line in Figure 2;

- among schools in different districts within the core municipality (Hc);

- among schools in different districts outside the core municipality (Hm);

- among different schools within individual school districts (Hw).

\section{Components of segregation}

The metropolitan areas we analysed show the importance of city centres for job opportunities and services, but also the relevant role played by surrounding residential belts in accommodating migrants. Nevertheless these areas are not showing strong ethnic segregation patterns. This settlement pattern also means that long-staying immigrant households with children are located in neighbourhoods where the availability of school facilities does not equate to the growth of school-age residents.

41 To demonstrate this process, we will focus on lower secondary schools. ${ }^{4}$ They are a weak point in the Italian educational system for two reasons. Firstly, as part of comprehensive, general and compulsory education, they are meant to be evenly distributed at local level and thus attended by nearby residents, ${ }^{5}$ but they are actually unevenly distributed, since institutional change (opening or closing schools) is slower than social change (settlement patterns of new inhabitants).

Secondly, they are selective both in their organization by subjects and in their actual effects (this is the level at which the gap by class, origin and area opens dramatically), thus showing more segregation than primary schools (Mussino, Strozza, 2012; De Simone, 2013).

43 The analysis will focus on datasets from the school years 2003/04 and 2010/11 provided by the Statistical Service of the Ministry of Education, University and Research ${ }^{6}$. In this time span, foreign pupils more than doubled in the four case studies (see Table 1).

The dataset includes the whole population of enrolled pupils by school, citizenship and city. The administrative label used to identify PIBs is "non-Italian citizens": this means that we cannot provide data on PIBs with Italian citizenship (i.e. with a native or naturalized Italian parent). Given that Italy-born children with foreign parents can naturalize just when 18, and naturalization rates were still low in the years we focussed on. Estimations on Census data show that the under-representation of PIBs should range between 4 and $8 \%$ (that is, less than $1 \%$ of the total number of pupils).

The growth of foreign pupils did not affect their segregation level, with a quite limited hindex compared to European and US cases (Kristen, 2008; Oberti, 2007; SCP, 2009; Alegre, Ferrer-Esteban, 2010). Nevertheless, the situation has not been static at all: the territorial components of the h-index show differences among the four cities in a) segregation models; b) patterns of change (Table 1 and Figure 1 ). 
Table 1. Context data, school population data (lower secondary schools only) and school segregation $(\mathrm{H}$ index) in selected provinces.

\begin{tabular}{|c|c|c|c|c|}
\hline & Milan & Bologna & Rome & Naples \\
\hline & \multicolumn{4}{|c|}{ Context } \\
\hline $\begin{array}{l}\text { \% foreign minors on resident minors } \\
\text { (2010) }\end{array}$ & 21.0 & 17.0 & 10.5 & 2.3 \\
\hline $\begin{array}{l}\% \text { of foreign minors on foreign } \\
\text { residents }(2010)\end{array}$ & 20.4 & 18.8 & 17.5 & 16.2 \\
\hline Unemployment rate (2010) & 5.8 & 4.9 & 8.9 & 15.6 \\
\hline \multirow[t]{2}{*}{ Employed in tertiary sector } & 75.4 & 69.0 & 84.2 & 74.7 \\
\hline & \multicolumn{4}{|c|}{ Policies } \\
\hline $\begin{array}{l}\text { Local migration policies (funding, } \\
\text { institutionalization) }\end{array}$ & $+/-$ & + & $+1-$ & - \\
\hline \multirow[t]{2}{*}{$\begin{array}{l}\text { Targeting of minors in local migration } \\
\text { policies }\end{array}$} & $+/-$ & ++ & $+/-$ & $+/-$ \\
\hline & \multicolumn{4}{|c|}{ Lower secondary schools and school segregation } \\
\hline Total pupils $(2003 / 04)$ & 105,427 & 23,283 & 124,472 & 133,662 \\
\hline Total pupils $(2010 / 11)$ & 106,794 & 24,793 & 119,480 & 119,357 \\
\hline Foreign pupils (2003/04) & 7,121 & 1,649 & 5,975 & 713 \\
\hline Foreign pupils (2010/11) & 14,266 & 3,719 & 11,948 & 1,671 \\
\hline $\begin{array}{l}\text { Foreign pupils as a percentage of } \\
\text { enrolled pupils (a.s. 2010/11) }\end{array}$ & 13.4 & 15.0 & 10.0 & 1.4 \\
\hline Schools $(2010 / 11)$ & 362 & 90 & 288 & 250 \\
\hline Segregation index $(H)(2003)$ & 0.1201 & 0.0628 & 0.0770 & 0.1790 \\
\hline Segregation index $(H)(2010)$ & 0.1094 & 0.0627 & 0.0718 & 0.0956 \\
\hline Relevant components of $\mathrm{H}$ index & $\mathrm{Hw}+\mathrm{Hcm}$ & Balanced & $\mathrm{Hw}$ & $\begin{array}{r}\mathrm{Hw}+ \\
\text { growing } \mathrm{Hm}\end{array}$ \\
\hline
\end{tabular}

SOURCE: DATA ON FOREIGN RESIDENTS FROM DEMO.ISTAT.IT; UNEMPLOYMENT DATA FROM DATI.ISTAT.IT; SCORES ON POLICIES BASED ON ANALYSIS INCLUDED IN THE PREVIOUS SECTION; DATA ON SCHOOLS AND SEgREgATION, OWN ELABORATION ON DATA FROM THE MINISTRY OF EDUCATION

Figure 1. School segregation index (H), components - school years 2003/2004 and 2010/2011.

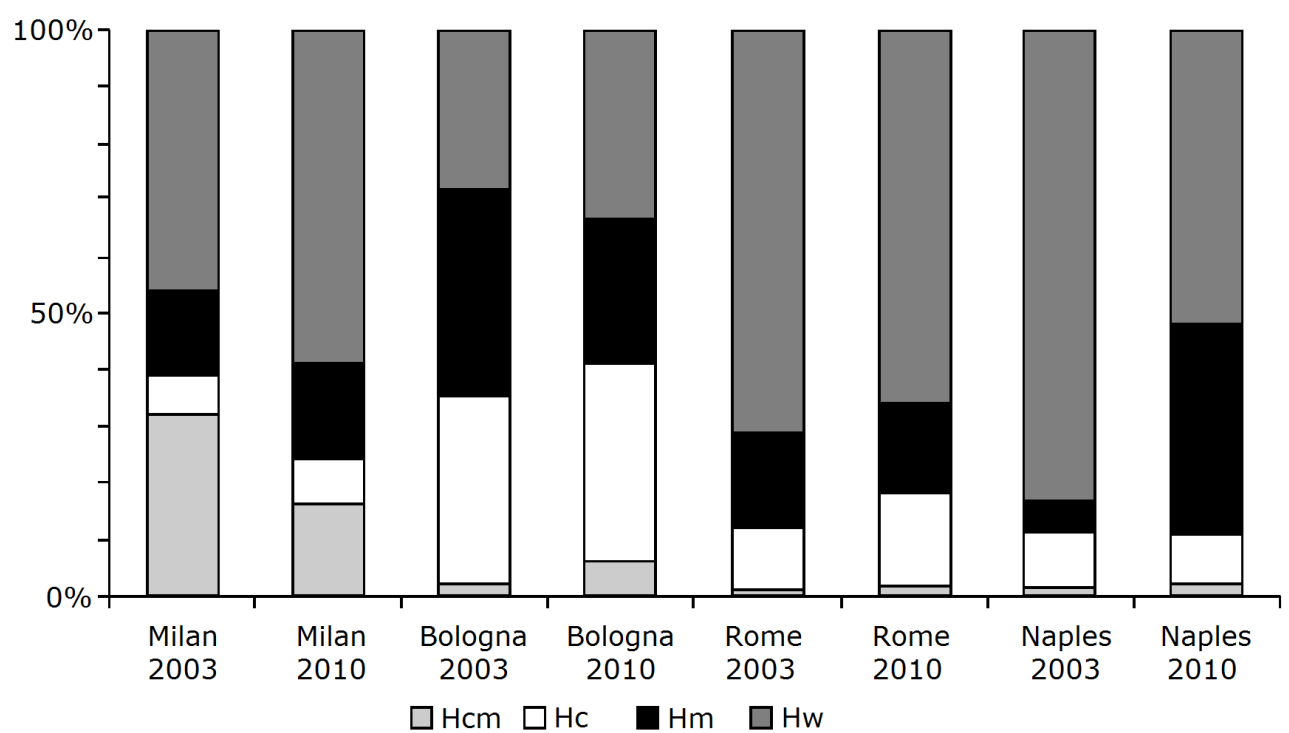

HW = SEgREgATION WITHIN INDIVIDUAL DISTRICTS; HM = SEgREgATION AMONg DISTRICTS OUTSIDE THE CORE MUNICIPALITY; HC = SEgREgATION AMONG DISTRICTS IN THE CORE MUNICIPALITY; HCM = SEgREgATION BETWEEN CORE MUNICIPALITY AND METROPOLITAN AREA

SOURCE: ELABORATION ON DATA FROM THE MINISTRY OF EDUCATION, UNIVERSITY AND RESEARCH 
46

We can see four different concentration models. Bologna has a more "balanced" (and lower) school segregation. Foreign pupils' concentration is due to their settlement in some urban working class areas and in some districts of the metropolitan belt (the ones mixing residential and productive functions). All in all, the segregation between and within districts is limited. Segregation between the core municipality and the rest of the metropolitan area increases due to the doubling of PIBs and the stability of Italian citizens pupils. Mapping the data, we can see a high concentration of PIBs in large schools in the north-western part of the city (Figure 2). Family reunifications increased the concentration in the core municipality, where you find most of long-lasting settled immigrant households (Comune Di Bologna, INFO-BO, 2012).

Figure 2. Share of national pupils and PIBs by school size. School year 2010/2011.

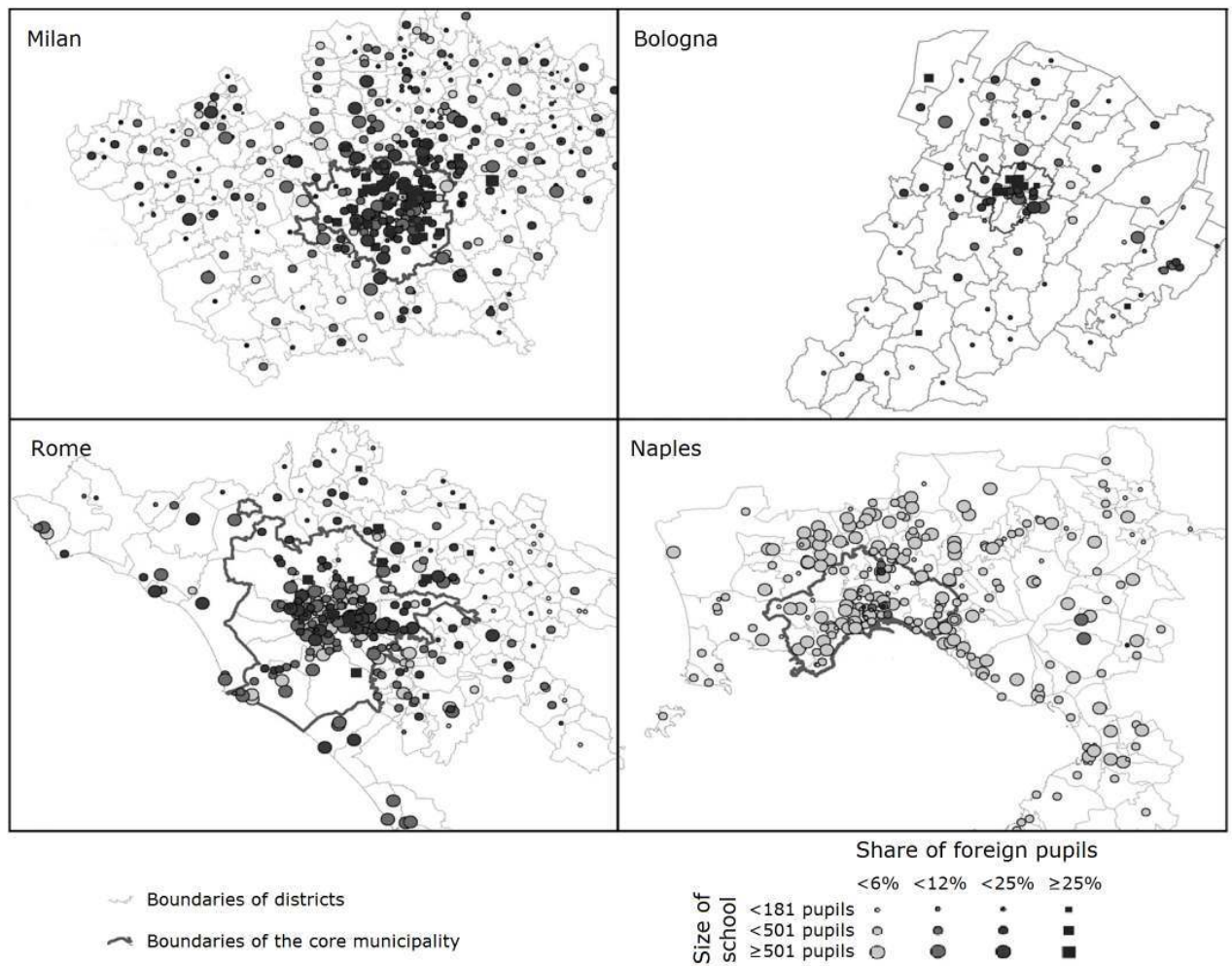

SOURCE: OUR ELABORATION ON DATA FROM THE MINISTRY OF EDUCATION, UNIVERSITY AND RESEARCH

In the wider metropolitan area, schools with higher shares of foreign pupils are in the north-western belt, a multi-specialized agro-industry area. This means also that the matching of productive and housing sprawl somehow contributes to limiting segregation via territorial dispersal.

In Milan, the most specific segregation dimension has to be found in the difference between the core municipality and the surrounding belt. This has no connection to residential patterns, but is instead due to the higher attractiveness, for Italian native pupils, of schools in the core city. However, within the core city there is a difference between centre and periphery, with possible evidence of a white flight from the latter (Ranci et al., 2016). Also, comparing data from 2003/04 and 2010/11, schools in the northern belt are becoming increasingly similar to those in the core city - contributing to some sort of de-concentration effect. 
On a lower scale, de-concentration also took place in Naples, where anyway the number of foreign pupils grew in just a few districts. Segregation here is mainly due to differences between districts in the urban belt: no school has more than $30 \%$ of foreign pupils and few (small) schools have a relevant share of PIBs.

Lastly, in Rome pupils living in the urban belt enrol in the urban belt, and those living in the core city enrol in the core city, and the most relevant component is the micro one, within every district. Every district in Rome has at least a fairly big school with a high share of PIBs (close to 25\%) and a small school with a share close to zero. At least six districts have schools with a very high share of PIBs. This is the case where the lack of an adequate governance of educational institutions is clearer, since school segregation is not so related with residential segregation.

1 In the urban belt, we can see two types of concentration areas: a) municipalities traditionally attracting populations coming from central Rome in suburbanization processes; b) rural depopulating towns, where the high share of PIBs is due to the sharp decrease of Italian nationals.

\section{Segregation scales and accessibility in education}

2 In general, the micro-dimension of school segregation seems to be the most important feature in most of our case studies. This issue requires a clarification on the Italian model of school segregation. Concentration can be due to a variable mix of factors:

- Residential (micro-)segregation pushing migrants in specific urban traits;

- White flight and sorting mechanisms (Ball et al., 1996), i.e. a quasi-market competition for scarce places in more attractive schools;

- Negative by-products of school policies;

- Problems in producing policies and measures for school integration: shortcomings in planning and managing complex and intermingled policies (education, labour market, housing, migration) - which should probably be coped at a higher scale.

To disentangle such a mix of factors, we will analyse small-scale examples that epitomize the local outcome of the rescaling and subsidiarization of policies. We will consider possible effects of individual choices, ethnic composition of districts and school offers. In particular, we focus here the role played by private schools: even if limited in the Italian context as mentioned above, they can be used as a proxy of individual choices (basically, the choice to leave the much prevalent public education).

In Milan, private schools have very few foreign pupils. This means an overburdening for nearby state schools - as in the north-eastern semi-periphery. Elusive and discriminatory strategies seem limited to the city centre, where the share of PIBs is limited.

In Bologna, private schools are not accessible to PIBs, and closeness to residence is the main factor that influences concentration. In some neighbourhoods, this leads to a quite extraordinary level of PIBs concentration, that also cumulates with other disadvantaged conditions for the local residents as a whole.

In Rome the situation is slightly different: many small, private religious schools include foreign pupils in different districts of the city. However, in Rome it is also common to see unbalances between schools in the same neighbourhood, likely due to parental elusive strategies. For example, in a north-western semi-central middle-class area there are two state schools, but PIBs are enrolled in only one, considered as the least exclusive. On the 
other hand, in the Esquilino district - a strongly multi-ethnic area in the city centre PIBs concentration in a single school is explained by that school's long-standing attention to PIBs integration policies. Although there are two other state schools within 800 metres, one school is attracting most PIBs, for it is also a service centre for intercultural education.

Lastly, Naples seems to reproduce same features analysed in the other three cities, though at a lower level, due to the limited number of foreign pupils.

\section{Conclusions}

58 The analyses above - and the context and summary data in Table 1 above - show that segregation effects are strongly based on localized (and sometimes even micro-local) processes intersecting settlement trends and (weak) policy arrangements. In a poorly regulated national context, the governance of migration - that we analysed from the specific point of view of the school participation of PIBs - is strongly related to the "spontaneous" interplay between labour and housing markets.

We could not find a clear-cut component to map school segregation. The distribution of PIBs follows settlement patterns based on specific local sources of attractiveness: affordable housing and labour market opportunities in Bologna are more scattered then elsewhere and contribute to a lower segregation, while local authorities may also benefit from a more effective local integration policy. Higher inequality in housing and labour market in service-based economies account for a higher segregation, especially in specific peripheral blocks.

The increasing number of pupils enrolled in the metropolitan belt requires the educational offer to be adequately set at least at metropolitan level, to avoid PIBs concentrations due to the scarcity of schools or the poorness of integration policies. So, part of the problem is due to unequal distribution of measures (as the Roman case shows) or to an inadequate planning of school offer in new residential areas - especially vulnerable ones.

61 As mentioned above, school segregation is still lower than in other Western countries, likely due to the comprehensive educational system and a limited residential segregation - a positive but not planned effect. Nevertheless, there is still much to study about microsegregation within neighbourhoods. Sometimes it is due to residential microconcentrations, in other cases due to filtering-out processes and white flights.

With a weak national attention to immigrant policy, problems are mostly dumped on single schools, making national goals hard to achieve without adequate support and shared practices. An ideal-type comprehensive educational system is on the ropes in a retrenchment era that jeopardizes the agency of school institutions, which are given responsibilities but limited resources, skills and governance networks to deal with them.

63 The management of vulnerable conditions (including migrant one) is not framed adequately in national policies, and this puts a high pressure on local policy networks, since schools do not have "in-house" professionals to face new challenges.

64 This is consistent with some well-known factors in the Italian welfare (Kazepov, 2010). Firstly, the problem of territorial fragmentation: the differences in the provision of services, infrastructures and resources do not reflect only a North/South divide (even 
though important, as Table 1 shows) but also a micro-dimension, that turns into a "postcode lottery" (living and studying in a city or neighbourhood means accessing very different basic provisions).

Secondly, the issue of coordination. School autonomy and decades of devolution redistributed responsibility, though with a lack of resources, thus paving the way for a "decentralization of penury" (Kazepov, 2010; Mény, Wright, 1985). Local resources and policy networks are unevenly endowed and may lack tools for an effective coping of emerging problems - including segregation. In this respect, school and local autonomy can turn into an inadequate tool for PIBs' integration, if not properly matched with institutional empowerment, capacitation tools, and resources to cope with devolved tasks.

\section{BIBLIOGRAPHY}

ALEGRE M.A., FERRER-ESTEBAN G. (2010), “How Do School Regimes Tackle Ethnic Segregation?”, in DRONKERS J. (Ed.), Quality and Inequality of Education, Heidelberg, Springer, pp. 137-162.

BALL S.J., BOWE R., GEWIRTZ R. (1996), “School choice, social class and distinction”, Journal of Education Policy, 11, Abingdon, Taylor \& Francis, pp. 89-112.

BALLARINO B., BERNARDI G., REQUENA M. \& SCHADEE H. (2009), “Persistent Inequalities? Education and Class Inequality in Italy and Spain”, European Sociological Review, 25, 1, Oxford, Oxford University Press, pp. 123-138.

BALLARINO G., CHECCHI D. (2006), Sistema scolastico e disuguaglianza sociale, Bologna, Il Mulino.

BRENNER N. (2004), New State Spaces, Oxford, OUP.

CAMPOMORI F., CAPONIO T. (2014), "Migrant reception policies in a multilevel system: framing and implementation structures in the Italian Regions", in HEPBURN E., ZAPATA-BARRERO R. (eds.), The Politics of Immigration in Multi-level States, Basingstoke, Palgrave, pp. 130-149.

COMUNE DI BOLOGNA, INFO-BO (2012), Ricongiungimenti familiari a Bologna, Opera dell'Immacolata (mimeo).

DE SIMONE G. (2012), "Render unto primary the things which are primary's: Inherited and fresh learning divides in Italian lower secondary education", Economics of Education Review, 35, Oxford, Elsevier, pp. 12-23.

DUNCAN O., DUNCAN B. (1955), “A Methodological Analysis of segregation indexes”, American Sociological Review, 20, Albany (N.Y.), American Sociological Association, pp. 210-217.

FERRERA M. (ed.) (2005), Welfare State Reforms in Southern Europe, New York, Routledge.

GAMBINO A. (2005), "Le politiche regionali", in GORI C. (ed.), Politiche sociali di centro-destra, Rome, Carocci, pp. 73-95.

GLICK SCHILLER, N., CAGLAR A. (2009), "Towards a Comparative Theory of Locality in Migration Studies", Journal of Ethnic and Migration Studies, 35, 2, Abingdon, Taylor \& Francis, pp. 177-202. 
GLICK SCHILLER N., CAGLAR A. (2010), Locating Migration, Cornell University Press, Ithaca. GRIMALDI E., SERPIERI R. (2012), “The Transformation of the Education State in Italy”, Italian Journal of Sociology of Education, 1, Padua, Padova University Press, pp. 146-180.

KAZEPOV Y. (2008), “The Subsidiarization of Social Policies”, European Societies, 10, 2, Abingdon, Taylor \& Francis, pp. 247-273.

KAZEPOV Y. (ed.) (2010), Rescaling Social Policies, Farnham, Ashgate.

KAZEPOV Y., BARBERIS E. (eds.) (2012), Il welfare frammentato, Rome, Carocci.

KRISTEN C. (2008), "Primary School Choice and Ethnic School Segregation in German Elementary Schools", European Sociological Review, 24, 4, Oxford, OUP, pp. 495-510.

LIPMAN P. (2010), "Education and the Right to the City", in APPLE M.W, BALL S.J., GANDIN L.A. (eds.), The Routledge International Handbook of the Sociology of Education, Routledge, London, pp. 241-252.

MARUCCI M., MONTEDORO C. (2010), "L'integrazione degli immigrati tra politiche attive del lavoro e politiche sociali", Strumenti ISFOL, 6, Rome, Isfol.

MÉNY Y., WRIGHT V. (1985), “General Introduction”, Centre-Periphery Relations in Western Europe, London, Allen \& Unwin, pp. 1-9.

MUSSINO E., STROZZA S. (2012), "The delayed school progress of the children of immigrants in lower-secondary education in Italy", Journal of Ethnic and Migration Studies, 38, 1, Abingdon, Taylor \& Francis, pp. 41-57.

NAPOLITANO G.M. (2012), “Le risorse per i migranti nei bilanci regionali dell'VIII legislatura”, in RONCHETTI L. (ed.), I diritti di cittadinanza dei migranti, Napoli, Giuffrè, pp. 368-369.

OBERTI M. (2007), L'école dans la ville, Paris, Presses de Sciences Po.

OECD (2011), "Private schools: Who benefits?", PISA in Focus, 7, Paris, OECD Publishing.

ORMEL (2004), Politiche per l'immigrazione in Campania, Napoli, Regione Campania.

PAVOLINI E. (2006), "Immigrazione, sistema educativo e politiche locali: il caso emilianoromagnolo”, Le istituzioni del federalismo, 3,4, Bologna, Regione Emilia-Romagna, pp. 455-488.

PUGLIESE E. (2008), "Il modello mediterraneo dell'immigrazione”, Quaderni di rassegna sindacale, 2, Rome, Ediesse, pp. 73-87.

REARDON S.F., YUN J.T. \& MCNULTY EITLE T. (2000), “The changing structure of School Segregation: Measurement and Evidence of Multiracial Metropolitan-Area School Segregation 1989-1995”, Demography, 37, 3, New York, Springer, pp. 351-364.

REGIONE EMILIA-ROMAGNA (2006), Report di analisi dei Piani di Zona 2005-2007 e dei Programmi attuativi 2005, Bologna (mimeo).

SANTAGATI M., ONGINI V. (eds.) (2016) Alunni con cittadinanza non italiana. La scuola nei contesti locali. Rapporto nazionale A.s. 2014/15, Milan, ISMU.

SCHIZZEROTTO A., TRIVELLATO U. \& SARTOR N. (eds.) (2011), Generazioni diseguali, Bologna, Il Mulino.

RANCI C., CORDINI M., MANFREDINI F. \& PARMA A. (2016), La segregazione scolastica a Milano, Unpublished paper, Milan, Politecnico di Milano.

SCP (2009), Making up the Gap: Migrant Education in the Netherlands, SCP, Den Haag. 
THEIL H., (1972), Statistical decomposition analysis, Amsterdam, North-Holland Publishing Company.

TOSI A., CAGNOLI R. \& TOSI S. (2012), "I progetti per l'integrazione degli immigrati nel territorio regionale", in ORIM (ed.), Rapporto 2011. Gli immigrati in Lombardia, Milan, Regione Lombardia, pp. 325-348.

\section{NOTES}

1. We define PIBs as the children of a parent born abroad, whatever their citizenship. This definition has been used for interviews, while data collection in the section "school segregation" - as reported below - is based on available citizenship data.

2. For a description of the Italian education system, see Eurydice page: https:// webgate.ec.europa.eu/fpfis/mwikis/eurydice/index.php/Italy:Overview.

3. Actually, the measure of diversity is not based on a simple proportion of the foreign group, but on the proportion multiplied by the natural logarithm of its reverse.

4. In the Italian educational system, they are attended by pupils aged 11-13.

5. Which is different from upper secondary schools, whose specialist subject tracks are considered a more important factor in choosing a school than their location.

6. Number of pupils and schools analysed are reported in Table 1. Italian and foreign pupils per school and localization have been studied. There are no missing data. Though, potential sources of distorsion come from definitions used by the Ministry: (a) there is no information on naturalized PIBs; (b) few school branches ( $2-4 \%$ per city) have no individual identifier. It is therefore impossible to geo-reference their location and pupils. Their data is thus counted under their reference school.

\section{ABSTRACTS}

This article is aimed to analyse processes of school segregation in four Italian metropolitan areas (Milan, Bologna, Rome, Naples), considering their linkages with the transformation of settlement trends and national and local immigration policies.

In this respect, rescaling processes imply an increased scope for an uncoordinated local action, affecting - among the other issues - how migrants settle and meet relevant institutions, including schools.

After introducing the different hub role of the four metropolitan areas for international migrants to Italy, school segregation will be analysed as an effect resulting from the interrelation of settlement patterns and institutional configurations. Examples of micro-segregation processes in every city will be used to disentangle the relation between scalar processes and localized agency.

Cet article a pour objet l'analyse des processus de ségrégation scolaire dans quatre régions métropolitaines italiennes (Milan, Bologne, Rome, Naples) sur base de leur rapport avec l'évolution des tendances d'établissement des immigrés et les politiques locales d'immigration. Dans ce contexte, les mécanismes de changement d'échelle impliquent des actions noncoordonnées au niveau local, qui concernent entre autres l'installation des migrants et leurs 
contacts avec les institutions, notamment avec les écoles.

Après avoir présenté les différentes fonctions de pôles de convergence nous analysons la ségrégation scolaire en tant que résultat de l'interrelation entre les schémas d'établissement et les configurations institutionnelles. Plusieurs exemples de processus de micro-ségrégation dans chacune des villes mettront en lumière la relation entre processus scolaires et institutions locales.

INDEX

Mots-clés: ségrégation scolaire, échelle territoriale, marché du travail local, politiques de l'éducation, régions italiennes

Keywords: school segregation, rescaling, local labour market, educational policy, Italian regions

\section{AUTHORS}

\section{EDUARDO BARBERIS}

University of Urbino Carlo Bo, eduardo.barberis@uniurb.it

ALBERTO VIOLANTE

ISTAT, alberto.violante@istat.it 